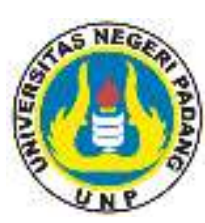

\title{
ANALISIS KESALAHAN PENGGUNAAN KATA KERJA FUTSUKEI PADA SAKUBUN MAHASISWA TAHUN MASUK 2017 PROGRAM STUDI PENDIDIKAN BAHASA JEPANG UNIVERSITAS NEGERI PADANG
}

W. H Happiness ${ }^{1}$, Hendri Zalman ${ }^{2}$

Program Studi Pendidikan Bahasa Jepang ${ }^{1}$ (Jurusan Bahasa dan Sastra Inggris, Fakultas Bahasa dan Seni, Universitas Negeri Padang)

Program Studi Pendidikan Bahasa Jepang ${ }^{2}$ (Jurusan Bahasa dan Sastra Inggris, Fakultas Bahasa dan Seni, Universitas Negeri Padang)

Email Penulis : whhappiness98@gmail.com

\begin{tabular}{ll}
\hline \multicolumn{3}{l}{ Sejarah Artikel } \\
\hline Submit $\quad: 2019-10-31$ \\
Diterima $: 2019-11-14$ \\
Diterbitkan : 2020-07-20 \\
\end{tabular}

Kata Kunci: Analysis,futsukei, Sakubun
Abstrak

This research aims at determining the forms, types and causes of errors made by the 2017 Japanese students in using futsukei Verbs in Japanese Language Education Study Program at Universitas Negeri Padang. This research was a descriptive qualitative. The source of the data in this research was the students' sakubun which was the students' writings. Based on the data analysis, there were 25 errors containing in 60 sakubun made by students. The form of morphological errors in the use of the word futsukei in the sakubun text in this research was $44 \%$ consisting of 3 errors in the verb futsukei ta, ru, and bu. The form of syntactic errors using the verb futsukei in the sakubun text in this research was $20 \%$ consisting 2 errors in the verb futsukei ta and ru. The types of errors in the use of the verb futsukei in this research that the authors could find only lapses or typographical errors that was $20 \%$. The cause of futsukei verb errors in this research lies in the competency factor. The number of competency factors found in this study was 4 errors (16\%).Based on the results of research on the use of the futsukei verbs in the students' sakubun, it was found that morphological errors were the highest errors with a percentage of $44 \%$, while the lowest errors was in the competency factor with a percentage of $16 \%$.

\section{PENDAHULUAN}

Bahasa merupakan alat komunikasi yang terpenting yang dibutuhkan manusia dalam menjalani aktivitas kehidupan sehari-hari. Dengan bahasa manusia dapat mengutarakan maksud hati dan pikirannya kepada orang lain. Seiring dengan kemajuan teknologi, komunikasi yang terjalin antar manusia tidak selalu

\footnotetext{
${ }^{1}$ Mahasiswa Prodi Pendidikan Bahasa Jepang FBS UNP lulus pada Desember 2019

2 Dosen Prodi Pendidikan Bahasa Jepang FBS UNP
} 
dalam bahasa yang sama karena beragamnya bahasa dari setiap negara di dunia. Oleh karena itu, timbul kebutuhan untuk mempelajari bahasa asing misalnya bahasa Jepang. Dalam mempelajari bahasa Jepang terdapat berbagai macam kendala. Kendala tersebut terdapat pada huruf yang digunakan, gramatikal, kosakata, dan sistem pengucapannya. Hal itu menjadikan bahasa Jepang sangat unik bagi penutur asing, salah satunya penutur Indonesia. Keunikan bahasa Jepang yang pertama yaitu dari segi huruf, dalam bahasa Jepang terdapat 4 (empat) macam huruf, yaitu: hiragana, katakana, kanji, dan romaji. Dalam menulis sebuah kalimat, penggunaan huruf ini dilakukan secara bersamaan. Akan tetapi, berbeda dengan bahasa Indonesia. Dalam bahasa Indonesia penggunaan huruf hanya menggunakan huruf latin. Hal ini menjadikan pembelajar Indonesia kesulitan dalam menguasai huruf bahasa Jepang. Kedua, dalam segi gramatikal, keunikan bahasa Jepang dapat dilihat dari tataran kata, frasa, dan kalimat. Pada tataran kata, kata dalam bahasa Jepang terdapat 6 (enam) kelas kata, yaitu: 1) kata benda (meishi), 2) partikel (joushi), 3) kata keterangan (fukushi), 4) kata kerja (doushi), kata sifat (keiyoushi), dan kopula (jodoushi). Keenam kelas kata ini lalu dikelompokkan menjadi dua, yaitu; kelompok kelas kata yang mengalami perubahan bentuk, dan kelas kata yang tidak mengalami perubahan bentuk. Meishi, joshi, dan fukushi adalah kelompok kelas kata yang tidak mengalami perubahan bentuk. Sedangkan doushi, keiyoushi, dan jodoushi termasuk ke dalam kelompok kata yang mengalami perubahan bentuk. Di antara 3 (tiga) kelas kata yang paling banyak mengalami perubahan bentuk sehingga memiliki potensi yang tinggi terhadap kesalahan dalam penggunaannya adalah doushi (Zalman, 2016:1).

Menurut Nomura (dalam Sudjianto, 2009:149) kata kerja (doushi) adalah salah satu kelas kata dalam bahasa Jepang, sama dengan ajektiva-i dan adjektiva- na menjadi salah satu jenis yougen. Kelas kata ini dipakai untuk menyatakan aktivitas, keberadaan, atau keadaan sesuatu. Doushi dapat mengalami perubahan dengan sendirinya menjadi predikat dan merupakan salah satu kelas kata yang sangat menarik, karena doushi dikelompokkan menjadi beberapa kelompok salah satunya doushi bentuk biasa/ futsukei. Doushi bentuk futsukei adalah doushi yang digunakan pada tingkatan yang paling dasar. Tingkatan ini dipakai oleh pembicara kepada lawan bicara yang sudah akrab.

Contoh kalimat;

\section{1. 生徒たちは文を作る}

Seitotachi wa bun o tsukuru.

Murid-murid membuat

kalimat

2. 日本へ行くとき、カメラを買

ったNihon e iku toki, kamera o

katta Ketika pergi ke Jepang, beli

kamera

Sutedi,( 2011:90)

Dari kedua contoh kalimat diatas, terlihat bahwa doushi futsukei perubahannya berbeda-beda. Artinya terdapat beberapa aturan yang berbeda 
dalam perubahan doushi futsukei yang membuat mahasiswa kesulitan dalam mempelajarinya sehingga siswa sering melakukan kesalahan.

\section{METODE PENELITIAN}

Metode penelitian adalah suatu cara yang digunakan untuk memecahkan permasalahan yang dihadapi didalam suatu penelitian. Jenis penelitian ini berupa penelitian deskriptif dangan analisis data kualitatif.

Menurut Sedarmayanti dan Hidayat (2016:33) menyebutkan penelitian deskriptif adalah suatu metode dalam penelitian fakta status sekelompok manusia, suatu objek, suatu kondisi, suatu sistem pemikiran ataupun suatu peristiwa pada masa sekrang dengan interpretasi yang tepat.

Widoyoko (2014:18) menyatakan analisis data kualitatif adalah data yang menunjukkan kualitas atau mutu suatu yang ada, baik keadaan, proses, peristiwa/ kejadian yang lainnya yang dinyatakan dalm bentuk pernyataan atau kata-kata. Analisis data kualitatif dilakukan untuk mengetahui hasil kesalahan siswa berupa penjelasan melalui kata-kata.

\section{HASIL DAN PEMBAHASAN}

Data yang dianalisis dalam penelitian ini adalah kesalahan penggunaan kata kerja futsukei pada sakubun mahasiswa tahun masuk 2017 Program Studi Pendidikan Bahasa jepang Universitas Negeri Padang.

Berdasarkan analisis data, ditemukan sebanyak 25 kesalahan dalam 60 buah sakubun. Didalam 25 kesalahan tersebut didapat beberapa kesalahan mengenai bentuk, jenis, dan penyebab kesalahan kesalahan penggunaan kata kerja futsukei pada sakubun mahasiswa tahun masuk 2017 Program Studi Pendidikan Bahasa jepang Universitas Negeri Padang .

Table 1. Temuan Kesalahan Penggunaan Kata Kerja Futsukei pada Sakubun Mahasiswa Tahun Masuk 2017 Program Studi Pendidikan Bahasa Jepang

\begin{tabular}{|c|c|c|c|c|c|c|}
\hline \multirow{2}{*}{ No } & \multirow{2}{*}{$\begin{array}{c}\text { Kesalahan } \\
\text { Kata Kerja } \\
\text { Futsukei }\end{array}$} & \multirow{2}{*}{ Frekuensi } & \multicolumn{4}{|c|}{ Persentase Kesalahan (\%) } \\
\hline & & & Morfologi & Sintaksis & Lapses & Kompetensi \\
\hline 1. & $T a(た)$ & 9 & $54.5 \%$ & $20 \%$ & $40 \%$ & 0,0 \\
\hline 2. & $R u($ る $)$ & 12 & $36.4 \%$ & $80 \%$ & $40 \%$ & $50 \%$ \\
\hline 3. & $B u(ふ ゙)$ & 1 & $9.1 \%$ & 0.0 & 0.0 & 0.0 \\
\hline 4. & Gi(ぎ) & 1 & 0.0 & 0.0 & $20 \%$ & 0.0 \\
\hline 5. & $\operatorname{Nai}($ ない) & 1 & 0.0 & 0.0 & 0.0 & $25 \%$ \\
\hline 6. & $T s u(つ)$ & 1 & 0.0 & 0.0 & 0.0 & $25 \%$ \\
\hline & Jumlah & 25 & & & & \\
\hline
\end{tabular}

Sejalan dengan rumusan dan batasan masalah penelitian pada pembahasan akan dibahas mengenai : (1) Bentuk kesalahan pada kata kerja futsukei dalam sakubun; (2)Jenis kesalahan pada kata kerja futsukei dalam sakubun; (3) Penyebab kesalahan pada kata kerja futsukei dalam sakubun mahasiswa Program Studi Pendidikan Bahasa Jepang Universitas Negeri Padang. 


\section{Bentuk Kesalahan}

\section{a. Morfologi}

Bentuk kesalahan yang ditemukan adalah bentuk kesalahan morfologi, yaitu kesalahan atau penyimpangan proses pembentukan kata dalam menggunakan kata kerja futsukei.

\begin{tabular}{|c|c|c|}
\hline $\begin{array}{c}\text { Kesalahan Kata Kerja } \\
\text { Futsukei }\end{array}$ & $\begin{array}{c}\text { Frekuensi } \\
\text { Kesalahan }\end{array}$ & Persentase (\%) \\
\hline$T a$ & 6 & $54.5 \%$ \\
\hline$R u$ & 4 & $36.4 \%$ \\
\hline$B u$ & 1 & $9.1 \%$ \\
\hline Jumlah & 11 & \\
\hline
\end{tabular}

\section{b. Sintaksis}

Bentuk kesalahan yang ditemukan adalah bentuk kesalahan sintaksis yaitu kesalahan yang terjadi karena susunan kalimat yang dibuat tidak sesuai dengan aturan susunan kalimat yang seharusnya. Dalam menggunakan kata kerja futsukei.

\begin{tabular}{|c|c|c|}
\hline $\begin{array}{c}\text { Kesalahan Kata Kerja } \\
\text { Futsukei }\end{array}$ & Frekuensi Kesalahan & Persentase (\%) \\
\hline$T a$ & 1 & $20 \%$ \\
\hline$R u$ & 4 & $80 \%$ \\
\hline Jumlah & 5 & \\
\hline
\end{tabular}

Berdasarkan data yang terkumpul, ditemukan 5 bentuk kesalahan sintaksis yang terjadi.

\section{Jenis Kesalahan}

\section{a. Lapses}

Bentuk kesalahan yang ditemukan adalah bentuk kesalahan lapses, yaitu kesalahan yang terjadi akibat ketidaksengajaan dan tidak disadari oleh penuturnya dalam menggunakan kata kerja futsukei.

\begin{tabular}{|c|c|c|}
\hline $\begin{array}{c}\text { Kesalahan Kata Kerja } \\
\text { Futsukei }\end{array}$ & Frekuensi Kesalahan & Persentase (\%) \\
\hline$T a$ & 2 & $40 \%$ \\
\hline$R u$ & 2 & $40 \%$ \\
\hline$G i$ & 1 & $20 \%$ \\
\hline Jumlah & 5 & \\
\hline
\end{tabular}

Berdasarkan data yang terkumpul, ditemukan 5 bentuk kesalahan lapses yang terjadi. 


\section{Penyebab Kesalahan}

\section{a. Kompetensi}

Penyebab kesalahan berbahasa yang ditemukan adalah bentuk kesalahan kompetensi yaitu kesalahan berbahasa yang diakibatkan karena faktor kemampuan yang dimiliki dan kurangnya pengetahuan dalam menggunakan kata kerja futsukei.

\begin{tabular}{|c|c|c|}
\hline $\begin{array}{c}\text { Kesalahan Kata Kerja } \\
\text { Futsukei }\end{array}$ & Frekuensi & Persentase (\%) \\
\hline$N a i$ & 1 & $25 \%$ \\
\hline$R u$ & 2 & $50 \%$ \\
\hline$T s u$ & 1 & $25 \%$ \\
\hline Jumlah & 4 & \\
\hline
\end{tabular}

Berdasarkan data yang terkumpul, ditemukan 4 Penyebab kesalahan kompetensi yang terjadi.

Jika dikaji dengan penelitian relevan hasil penelitian ini hampir sama yang di teliti oleh Oktaviani (2018) dengan judul "Analisis Kesalahan Perubahan Doushi bentuk-te Pada Siswa Kelas XI IPA 1 SMA NEGERI 8 PADANG". Penyebab kesalahan dalam penelitian ini yaitu kesalahan yang terjadi dalam bentuk dan jenis ketika mengubah doushi bentuk-te. Bentuk kesalahan yang ditemukan dalam penelitian ini adalah bentuk kesalahan morfologi. Kesalahan morfologi terjadi sebanyak $18 \%$. Kesalahan morfologi ini terjadi karena salah dalam pembentukan doushi bentuk-te. Kesalahan ini diduga karena siswa salah memilih pembentukan doushi bentuk-te yang tepat. Jenis kesalahan yang ditemukan dalam penelitian ini adalah jenis kesalahan mistake, lapses dan error.

\section{KESIMPULAN}

Berdasarkan pembahasan yang telah penulis lakukan tentang analisis kesalahan penggunaan kata kerja futsukei pada teks sakubun mahasiswa tahun masuk 2017 program Studi Pendidikan Bahasa Jepang Universitas Negeri Padang, penulis dapat menyimpulkan bahwa:

1. Bentuk kesalahan morfologi pada penggunaan kata kerja futsukei pada dalam teks sakubun pada penelitian ini sebanyak 44\% terdapat 3 kesalahan pada kata kerja futsukei ta,ru, dan bu. Kata kerja futuskei ta ada 6 kesalahan dengan persentase $54,5 \%$, futsukei ru ada 4 kesalahan dengan persentase $36,4 \%$, futsukei bu ada 1 kesalahan dengan persentase $9,1 \%$.

2. Bentuk kesalahan sintaksis penggunaan kata kerja futsukei pada dalam teks sakubun pada penelitian ini sebanyak $20 \%$ terdapat 2 kesalahan pada kata kerja futsukei ta dan ru. Kata kerja futsukei ta ada 1 kesalahan dengan persentase $20 \%$, kata kerja futsukei ru ada 4 kesalahan dengan persentase $80 \%$.

3. Jenis kesalahan penggunaan kata kerja futsukei dalam penelitian ini yang dapat penulis temukan hanya kesalahan jenis lapses atau salah tulis sebanyak 20\%. Jumlah lapses dalam teks sakubun penelitian ini terdiri dari; kata kerja 
futsukei ta sebanyak 2 kesalahan dengan persentase 40\%, kata kerja futsukei $r u$ sebanyak 2 kesalahan dengan persentase $40 \%$, kata kerja bentuk futsukei gi sebanyak 1 kesalahan dengan persentase $20 \%$.

4. Penyebab kesalahan kata kerja futsukei pada penelitian ini terdapat pada faktor kompetensi. Yang mana faktor kompetensi adalah kurangnya kemampuan dan pengetahun yang dimiliki oleh mahasiswa. Jumlah faktor kompetensi yang ditemukan dalam penelitian ini ada 4 kesalahan dengan persentase $16 \%$. Kesalahan yang ditemukan yaitu pada kata kerja futsukei ru, nai dan $t s u$. Kata kerja futsukei ru terdapat 2 kesalahan dengan persentase $50 \%$, kata kerja futsukei nai terdapat 1 kesalahan dengan persentase $25 \%$, kata kerja futsukei tsu terdapat 1 kesalahan dengan persentase $25 \%$.

\section{REFERENSI}

3A Corporation. 2013. Minna no Nihongo Shokyu I. Surabaya. International Multicultural.

Alim, Burhanuddin. 2014. Ayo Belajar Bahasa Jepang. Yogyakarta: Graha Ilmu.

Annisac, Nurul, Sitti Fatimah, Hendri Zalman. 2018. "Hubungan Penguasaan Goi dengan Kemampuan Sakubun Mahasiswa Semester III Tahun Ajaran 2017/2018 Program Studi Pendidikan Bahasa Jepang Universitas Negeri Padang". Omiyage. Vol.1.No 1. Padang: UNP.

Aruan, Linda. 2009. Analisis Kesalahan Berbahasa di dalam Karangan Mahasiswa Program Studi Bahasa Jerman FBS Universitas Negeri Medan. Jurnal.Medan: Unversitas Negeri Medan.

Chaer, Abdul. 2007. Linguistik Umum. Jakarta: Rineka Cipta.

Dewi, Ratna Sari. 2018. Analisis Kesalahan Penggunaan Yari Morai (Beri Terima) Pada Mahasiswa Tahun Masuk 2016 Program Studi Pendidikan Bahasa Jepang. Skripsi. Padang: UNP.

Diner, Lispidona.2009.“Analisis Kesalahan Penggunaan Ungkapan yang Menunjukkan Waktu ( Kala dan Aspek ) dalam Karangan Bahasa Jepang”. Lingua, V(2). 130-139. UNNES.

Harisal, 2015. Analisis Kesalahan Dalam Karangan Bahasa Jepang Mahasiswa Sastra Jepang Universitas Hasanuddin. Tesis. Makasar: Universitas Hasanuddin. Diakses pada 11 juli 2019 https://docplayer.info/35015229Analisis-kesalahan-dalam-karangan-bahasa-jepang-mahasiswa-sastrajepang-universitas-hasanuddin.html

Khairat, Fadillatul. 2017. “Analisis Kesalahan Penggunaan Huruf Hiragana (ひらが な) Siswa Kelas XI IPS SMAN 2 Pariaman Tahun Ajaran 
2016/2017'.Skripsi. Padang: UNP.

Muhlisian, Asep Achmad. 2013. "Analisis Kesalahan Penerjemahan Bahasa Jepang yang Terdapat Dalam Karya Ilmiah Mahasiswa S2". Jurnal Pendidikan Bahasa Jepang ASPBJI (Gakkai) Korwil Jabar. Vol 7,No 1. Bandung:UPI.Diakses pada 11 juli 2019.

Oktaviani, Desi.2018. “Analisis Kesalahan Perubahan Doushi Bentuk-Te Pada Siswa Kelas XI IPA 1 Negeri 8 Padang. Skripsi. Padang:UNP

Putri, Ikhlas.2018. “ Analisis Penggunaan Josuushi Mahasiswa Tahun Masuk 2017 Program Studi Pendidikan Bahasa Jepang Universitas Negeri Padang.Skripsi. Padang:UNP.

Sedarmayanti dan Hidayat, Syarifudin. 2011. Metodologi Penelitian. Bandung: CV. Mandar Maju.

Setyawati. Ai Sumirah. dkk.2015. “Analisis Kesalahan Futsukei dalam Klausa Penjelas Meishi Shuushoku Pada Sakubun Mahasiswa Semester IV Prodi Pendidikan Bahasa Jepang UNNES”. Skripsi. Semarang : UNNES.

Sudjianto \& Dahidi, Ahmad. 2009. Pengantar Linguistik Bahasa Jepang. Jakarta: Kesaint Blanc.

Suhartini. 2016. “Analisis Kesalahan Penggunaan Sistem Kala Pada Pembelajar Bahasa Jepang Tingkat Dasar di Indonesia". Izumi.vol 5.No 2. Univesitas Teknologi Yogyakarta.

Sutedi, Dedi.2011. Dasar-Dasar Linguistik Bahasa Jepang. Bandung: Humaniora. Sutedi, Dedi. 2011. Penelitian Pendidikan Bahasa Jepang. Bandung: Humaniora Widoyoko. Eko Putro. 2014. Penilaian Hasil Pembelajaran di Sekolah.Yogyakarta : Pustaka Pelajar.

Zalman, Hendri. 2014. Kosa Kata Bahasa Jepang. Padang: UNP Press.

Zalman, Hendri 2016. Analisis Kesalahan Modifikasi Doushi Renyoukei pada Mahasiswa Bahasa Jepang FBS UNP Tahun Masuk 2014. Puitika:Jurnal Humaniora 12(1). Padang:Unand.

Zalman, Hendri 2016. Stategi Pemproduksi Bahasa yang Berpotensi Memunculkan Kesalahan: Kesalahan Memodifikasi Doushi pada Tes Bunpo Mahasiswa. Komposisi. Padang : UNP.

Zalman, Hendri. 2017. "Analisis Kesalahan Mahasiswa Program Studi Pendidikan Bahasa Jepang UNP dalam Memodifikasi Keiyoshi". Laporan Penelitian. Padang: UNP 